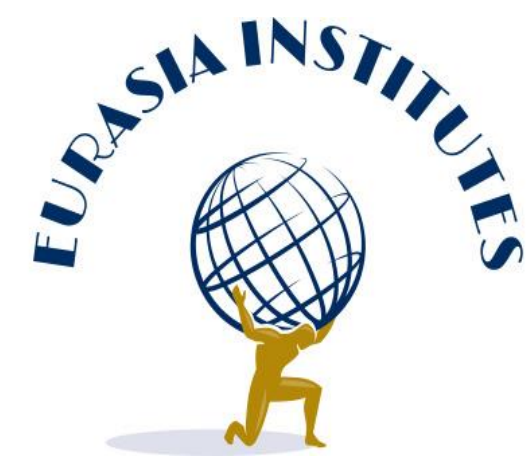

DOI: 10.47669/PSPRP-5-2020

\title{
New President, Old Problems: The Challenges of Post-Nazarbayev State- Building in Kazakhstan
}

Aram Terzyan

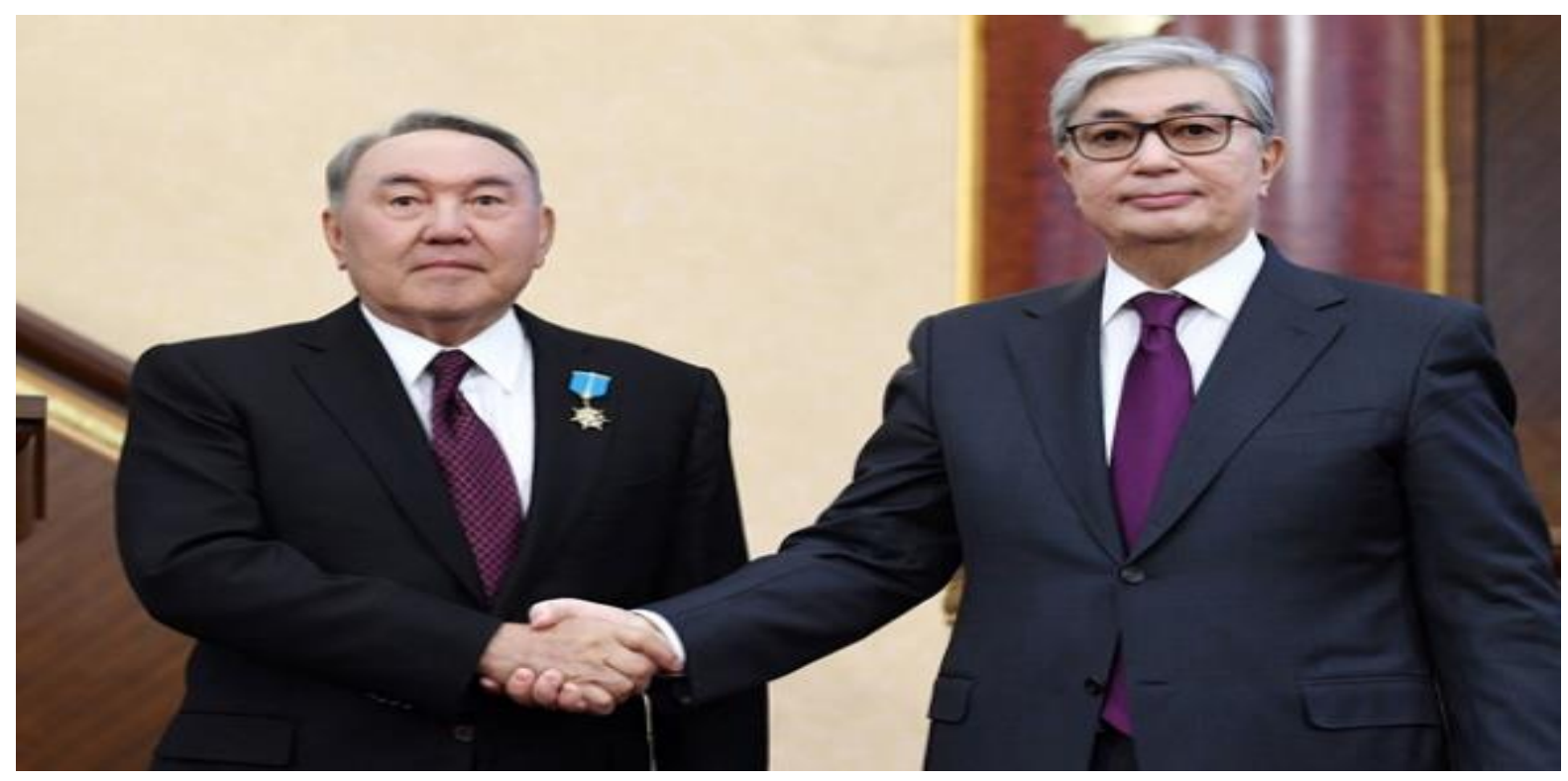

Center for Central Asian Studies 


\begin{abstract}
This paper explores post-Nazarbayev state-building in Kazakhstan, focusing on domestic and foreign policy implications of the power transition. After thirty years of incumbency, President Nursultan Nazarbayev stepped down in 2019, smoothly transferring the power to his nominee, Kassym-Jomart Tokayev, and thus plunged the country into a sensitive phase of power transition. This study suggests that the power transition in Kazakhstan has not led to significant improvements in terms of human rights and political freedoms protection, leaving the state of the weak opposition and constrained civil society intact. Kazakhstan keeps maintaining the core features of oil-rich countries, with hydrocarbon-based economy and regime stability stemming from an "authoritarian bargain" between the state and society. Besides, there has been continuity in foreign policy, with Kazakhstan further pursuing a multi-vectoral foreign policy agenda.
\end{abstract}

Keywords: Kazakhstan, Nazarbayev, power-transition, regime stability.

\title{
Introduction
}

With the resignation of Kazakhstan's long-serving President Nursulatan Nazarbayev in March 2019, the country plunged into a sensitive phase of power transition.

In his speech, the president admitted that the decision was "not easy" but motivated by his desire to pave the way for "a new generation of leaders" (BBC, 2019). However, Nazarbayev became the chair of the National Security Service, which gives him every tool to influence Kazakhstan's both domestic and foreign policies. That said, while controlling the decision making from offstage, Nazarbayev's "veto" remains critical to shaping Kazakhstan's political landscape (SWP, 2019).

Former Prime Minister Kassym-Jomart Tokayev's election as Kazakhstan’s President is a vivid testament to the lack of alternatives to the continuity of Nazarbayev's legacy. A question arises as to whether the domestic change will positively correlate with political and economic reforms across Kazakhstan?

This study specifically addresses the following research questions:

1. What are the core characteristics of Nazarbayev's legacy and how does the latter affect Kazakhstan's political and economic transformations?

2. Whether and to what extent has the state of human rights and political freedoms improved in post-Nazarbayev Kazakhstan?

3. What are the major foreign policy implications of the power transition?

The paper will proceed as follows: the first part will briefly discuss Nazarbayev's political legacy. The second part will focus on the main features of post-Nazarbayev state- 
building. The issues, pertaining to human rights, political economy and foreign policy will be addressed thereafter. The conclusion will summarize main findings.

\section{Nazarbayev's legacy and the challenges of political transformation}

The legacy inherited from President Nazarbayev is mixed. While having the most powerful economy in Central Asia, Kazakhstan is characterized by authoritarian practices and high level of corruption. Even though Kazakhstan has been attempting to take a lead role in driving public sector reforms in the Central Asian region, it has achieved limited success in addressing the seemingly intractable problem of corruption (Janenova and Knox, 2020).

Kazakhstan is the 113 least corrupt nation out of 180 countries, according to the 2019 Corruption Perceptions Index reported by Transparency International (Trading Economics, 2020).

Essentially, Kazakhstan's robust economy has been critical to ensuring regime stability. Kazakhstan has provided the economic exemplar for other Commonwealth of Independent States (CIS) countries since its independence in 1991 following the collapse of the Soviet Union. It has been classified by the World Bank as an 'upper middle income' country and witnessed sustained growth in spite of the global recession (Knox and Yessimova, 2015).

In terms of economic development, Kazakhstan was outpacing neighboring countries providing high living standards for its citizens and thus offseting the restriction of their freedoms. Studies show, that Nazarbayev's perceived charismatic leadership as the father of the Kazakhstani nation, and the single politician capable of meeting the challenges of postSoviet nation-building, has resonated with public attitudes towards him at the societal level (Isaacs, 2010).

Furthermore, in the absence of a robust political opposition and a vibrant civil society, there would be no formidable threat to the ruling regime (Bátor and Ondrejcsák, 2016). In effect, NGOs in Kazakhstan are weak and unsustainable. The explanations of institutional ineffectiveness lay in disconnect with local traditions, low visibility of NGOs, and unsupportive government. Moreover, survey of general population suggests that people in Kazakhstan know little about NGOs and do not appreciate their utility (Nezhina and Ibrayeva, 2013). 
Despite some of Nazarbayev's tangible accomplishments in nation-building, it has not been uncommon for the ruling regime to be denounced for deep-rooted authoritarian practices. The Kazakh leadership has tended to expand its coercive capabilities - not least through upgrading policing in rural areas to improve intelligence gathering on the local population and predict the rise of any anti-government activities. While doing so, however, the Kazakh leadership sought to frame its actions as an inclusive process that was sensitive to the grievances of the affected populations and the general public (Marat, 2016).

Governed by a soft authoritarian regime, the country is endowed with significant natural resources and yet deploys advanced forms of institutional legitimation, especially through its party of power (Del Sordi, 2016).

Even though Nur-Otan, Nazarbayev's party, enjoys huge public support, the long-term dominance at different levels of public administration has undermined political pluralism, thus blurring the distinction between the state and the party (OSCE, 2016). Nevertheless, the dissatisfaction with the authoritarian practices would be offset by increasing oil prices and accompanying economic development. In terms of regime durability in oil-rich countries, it is noteworthy, that their leaders have a strong tendency of using oil profits to increase popular support, to deter potential opposition and to secure elite loyalty (Kendall-Taylor, 2012).

In effect, Nazarbayev's mantra "economy first, then politics" and the accompanying solid economic performance has long helped the president to consolidate his power and maintain regime stability (Euronews, 2010).

Some students build on the social contract theory, according to which the state and the citizens sign a contract, whereby citizens accept "the rules," including some limitations to their freedoms, in exchange for having government take care of their well-being, security and basic rights (Boucher and Kelly, 1994). This comes down to an "authoritarian bargain" by which citizens relinquish political rights for economic security (Desai, Olofsgård and Yousef, 2009).

Consistent with the ruling elites' authoritarian legitimation strategies in oil-rich countries, Nazarbayev would attribute the persisting economic and political shortcomings to external factors, such as dwindling oil prices, geopolitical crises, global fluctuations, etc. (Nazarbayev, 2014).

The economic developmental component in Nazarbayev's ideological discourses was primarily an exercise of control over regional economic and political elites and that helped building further legitimacy for the regime in various socio-ethnic constituencies on both the 
regional and central levels. Notably, Kazakhstan 2030 Strategy for development was deployed by the regime to substitute the Soviet version of ideology, legitimize the regime among various ethno-lingual audiences, and discipline the behavior of regional elites (Kudaibergenova, 2015).

Overall, Kazakhstan demonstrates how authoritarian regimes can rely on a combination of charismatic, traditional and legal-rational claims to evoke legitimation (du Boulay and Isaacs, 2019).

There are several issues, that merit emphasis in post-Nazarbayev Kazakhstan: First, while making symbolic gestures, such as renaming the capital city after Nur-Sultan, the authorities would give less weight to carrying out social and political reforms. The authorities' inactivity triggered mass protests that undermined presidential elections, leading to Tokayev's landslide victory (70\% of the votes). Notably, the OSCE (2019) reports pointed to significant electoral irregularities, including serious violations of basic political freedoms. Around 500 activists were arrested on the election day and extended further. Such a crackdown, in turn provoked critical statements from the international community (Kussainov, 2019; Putz, 2019). It follows the transition was not smooth, and the legitimacy of Tokayev can be questioned.

The second factor that merits emphasis is so-called "double power" by Tokayev and Nazarbayev. The presidential decree that came into force in July 2018, granted Nazarbayev the right to lead the Security Council "for [his] lifetime due to his historic mission" (Radio Liberty, 2018). Under the decree, the status of the body was changed from consultative to constitutional, increasing its clout. That said, Nazarbayev has been equipped with every tool to influence not only domestic policies, but also the foreign and security policy from offstage (Security Council of the Republic of Kazakhstan, 2020). Along with ministers and local governors, President Tokayev periodically reports back to Nazarbayev (Mihr, 2020).

During the Nazarbayev era, the decisions came from one center, whereby the leader had the power to administer discipline over powerful groups. Those groups were formed around either the members of the inner cycle of decision makers or in accordance with the segmentation of the country. The complication brought about by the current system of "double system" is that those groups may use the power of external players to seize some advantages over their competitors. This could increase the likelihood of foreign players' interference in the Kazakh domestic politics (Vielmini, 2019). Against this backdrop, 
charging Tokayev's advisor Konstantin Syroezhkin with espionage for China is noteworthy. He was detained by the National Security Service without any official explanation (Grove, 2019).

Third, the gradual elevation of the younger or post-Soviet generation to the important positions of political leadership is likely to positively affect country's political landscape, not least through leading to improvements in terms of human rights and political freedom protection (The Astana Times, 2020; Vielmini, 2019).

Another set of possible changes has to do with national minority rights, with Russians being the biggest minority group. Nevertheless, studies show that Russian-speaking minorities largely accept their status beneath the Kazakh 'elder brother' and do not wish to identify as a 'national minority'. Furthermore, they affirm passive loyalty to the political status quo while remaining disinterested in political representation (Blackburn, 2019).

Further developments in this regard depend on the ability of those groups to find common articulation of their interests and demands, as well as on their ability to push for changes.

\section{The challenge of transformational change in the economy}

Clearly, the economic and political landscapes of every single country are intertwined. Historically, Kazakhstan's economy has been predominantly reliant on oil and gas extraction, with other sectors of economy being under-developed. Thus, one of the highly desired outcomes of the power transition is economic diversification.

Against this backdrop, factors hindering the economic development of the country have much to do with the government retarding the modernization and diversification of the economy. Given Kazakhstan's low population density and distance from export markets, the establishment of competitive and highly productive branches of the economy becomes challenging (Bohr et al., 2019). As of 2018, crude petroleum had the biggest share of export with almost $60 \%$ (OEC, 2019).

Remarkably, the main exported goods of Kazakhstan for the period 2000-2015 is the commodity group "Mineral products", which accounts for no less than $65.8 \%$ of total exports of Kazakhstan (Elena et al, 2016). It follows, that the country's economy inevitably finds itself in a vulnerable position amid the instability and decline in world oil prices.

In the middle of the 2000s it became clear to the government of Kazakhstan that resource-based model is also prone to economic volatilities. The economic crisis of 2008 reassured the government in this belief. As a result, in 2010 Kazakhstan started transitioning 
to active industrial policy to diversify its economy. Thus, the State program of accelerated industrial and innovative development (SPAIID) for 2010- 2014 was born (Konkakov and Kubayeva, 2016, p. 14).

Kazakhstan's government has strived to diversify away from oil exports through implementing structural and institutional reforms. Nevertheless, studies show that progress has been limited as the country's export basket is highly concentrated and still dominated by oil. This suggests that Kazakhstan should ensure better implementation, coordination, monitoring and evaluation of its diversification initiatives under Tokayev's presidency (Zhelev, 2019).

There is a broad consensus among the students of Kazakhstan's economy, that structural transformation of the country's poorly diversified economy should be based on the accelerated development of the manufacturing industry, the increase in non-commodity exports and the attraction of foreign direct investment in non-commodity sectors (Aubakirova, 2020).

Notably, Kazakhstan 2050 Strategy, has set the ambitious goal of becoming one of the top 30 developed countries in terms of per capita income by 2050. Some observers suggest that the strategy will also help manage, though not eliminate, the two major risks the country faces in its march towards becoming a top 30 developed economy: the risk of suffering from the so-called "resource curse" and of getting mired in the "middle income trap" (Aitzhanova, 2014).

Besides, the Kazakh leadership would give great weight to transport and logistics development (Nazarbayev, 2012). Clearly, the revival of the economic belt of the Great Silk Road opens up new significant opportunities for countries along the route to develop the economies of these countries. The main factors for the integration of these countries are logistics, international trade, and tourism. Between China and Russia and East Asia and Europe, Kazakhstan's strategic position on the New Silk Road empowers it as a logistics linchpin. Combining Kazakhstan's geographic position, political stability, relatively high per capita income, highly developed energy sector and the fact that the old Silk Road ran along Kazakhstan's southern border has catalyzed development of an integrated transport complex where logistics, air transportation and financial and business services come together to promote establishment of regional headquarter hubs. While this vision is highly promising 
for Kazakhstan, sophisticated planning, and development under Tokayev's presidency is necessary to translate it into reality (Selmier II, 2020).

Overall, the success of Tokayev's economic agenda significantly depends on the broader anti-corruption efforts that have not yielded tangible results by far (Janenova and Knox, 2019).

\section{The State Human Rights}

"Stability first" mantra that dominated Nazarbayev's discourse throughout his presidency would overemphasize the economic accomplishments, while downgrading human rights problems. Meanwhile, Tokayev's rise to power would reportedly create an enabling environment for substantial democratic reforms.

Significant human right problems in Kazakhstan include restrictions on political participation, suppression of dissent, lack of media independence, torture, and killings by or on behalf of the government, dissemination of corruption, people trafficking, etc. (US Department of State, 2019).

Freedom of expression has been severely limited in Kazakhstan, with the authorities silencing dissent through detaining, imprisoning dissidents, or pressing administrative charges against them (US Department of State, 2019). Moreover, libel is a criminal offense in Kazakhstan and the criminal code prohibits insulting the president (Freedom House: Kazakhstan, 2019).

However, as reported by the Freedom House, there has been an improvement in terms of freedom of assembly.Even though the general picture remains severe, the government would allow small group demonstrations after the presidential elections (Freedom House, 2020).

As for minority rights, it is noteworthy that vulnerable minorities in Kazakhstan are poorly protected and face wide and varied forms of discrimination. This is especially true for LGBT community members. Kazakhstan's Ministry of Defense classifies homosexuality as a "mental disorder" and bans gays from performing military service (Terzyan, 2020, p. 8). Overall, beatings, workplace dismissals, and online and real-life bullying remain common in Kazakhstan (Fershtey and Sharifzoda, 2019).

Poor prison conditions remain a significant concern with multiple cases of physical abuses, torture and beatings resulting in death. Those crimes were committed by prisoners who were privileged by the administrations of the prison for carrying out orders (US Department of State, 2019). Alarmingly, Galy Baktybayev, human rights defender and social 
activist - famous for raising the issues of corruption, was killed after surviving an assassination attempt, (Li, 2019).

The situation is compounded by the absence of independent bodies designed to investigate such crimes. The investigations are mainly carried out by the Police or State AntiCorruption Bureau, since The Special Prosecutor's Service of the Prosecutor General's Office is not entitled to investigate such cases (Amnesty International, 2019).

It follows, that under Tokayev's presidency much needs to be done to eradicate severe human right violations and ensure the protection of fundamental freedoms.

\section{Continuity in foreign policy}

For decades, Nazarbayev's administration successfully implemented multi-vectoral foreign policy, whereby Kazakhstan balanced its relations with China, Russia, the United States, and the European Union (Stronski, 2016). Meanwhile, since the collapse of the Soviet Union Kazakhstan's relations with neighboring countries, i.e. Kyrgyzstan, Tajikistan, Turkmenistan, and Uzbekistan have been characterized by tensions and disputes (Bohr, et al. 2019). Kazakhstan has tended to act as more of a global, rather than a regional actor. With the view to fulfilling its "regional agenda" Kazakhstan has consistently strived to strengthen ties with East Asian regional powers. Namely, Singapore has been treated as a desired partner, and a role model for development, despite the essential differences between the two countries. Singapore is not landlocked unlike Kazakhstan, and has successfully diversified its economy, along with effective anti-corruption policy. Against this backdrop, many students from Kazakhstan get granted scholarships to study at the Lee Kuan Yew School of Public Policy at the National University of Singapore, aimed at getting them exposed to Singapore's unique experience and sharing it with their homeland (Stronski, 2016).

In effect, multi-vectoral foreign policy is deemed to be one of the most significant parts of Nazarbayev's legacy. Having previously served as Premier and Foreign Minister, as well as Director General at the United Nations Office in Geneva, Tokayev is considered a prominent diplomat, and one of the architects of Nazarbayev's multi-vectoral foreign policy strategy.

The current Foreign Policy concept of the Republic of Kazakhstan for 2020-2030 was approved by the decree of the President on March 6, 2020. Resting on the analysis of the current situation and international experience, the document identifies basic principles, goals, objectives, trends, along with the main vision of the country's foreign policy. The novelty of 
the concept is the identification of the core challenges to the foreign policy, including crises of confidence, disseminating conflicts, erosion of the fundamental principles of the international law, conflict between nationalism and globalism, etc. Against this backdrop, the concept stresses the necessity of remaining committed to Nazarbayev's multi-vectoral and pragmatic foreign policy agenda (Administration of Affairs of the President of the Republic of Kazakhstan, 2020). Asserting and maintaining Kazakhstan's lead in the region is one of the core objectives of its foreign policy straregy (Chebotaryov, 2020).

Notably, Kazakhstan is deemed to be the major local partner of the EU and the USA in Central Asia. As noted by General Joseph L. Votel, then Commander of U.S. Central Command, Kazakhstan is the "the most mature and forward-thinking country in Central Asia" (Lawrence, 2019).

In the Western eyes, Kazakhstan has gained a reputation of a reliable partner due to its performance as the chair of the OSCE in 2010 and as a UN Security Council member in 2017-2018. Kazakhstan is the only Central Asian country engaged in the Individual Partnership Action Plan of NATO. The scope of cooperation includes cooperation on democratic, institutional and defense reforms (NATO, 2017). Intensifying partnership with Kazakhstan has been of crucial relevance to the US in terms of its foreign policy towards the region, not least due to the country's active engagement with Afganistan. That said, the US will further give great weight to deepening ties with Kazakhstan (Gegelashvili and Modnikova, 2019).

The 2020 was an important year in EU-Kazakhstan relations since the New Enhanced Partnership and Co-operation Agreement (ECPA) came into force, aimed at broadening economic, political and social partnership (Tileuberdi, 2020). Kazakhstan's expanding economic and security partnership with Europe is an integral part of its multi-vectoral foreign policy geared at balancing its ties with Russia, China, the Western states and the Muslim world (Dave, 2008). The European approach to Kazakhstan is conditioned by its energy security priorities with the issues of democracy and human rights relegated to the margins (Collins and Bekenova, 2017).

Kazakhstan has skillfully utilized its geostrategic location as a corridor between Asia and Europe and the country's rising profile as a crucial oil exporter to Europe and is likely to seek further rapprochement with the EU under Tokayev's presidency.

Essentially, Tokayev's first official visit to Russia in the capacity of the president is a symbolic demonstration of Russia's strategic importance to Kazakhstan (Altynsarina, 2019). 
Among other things, Kazakhstan's membership in the Russian-led organizations, such as the Eurasian Economic Union and CSTO prompts the Kazakh leadership to treat Russia as a strategic and a "special" partner.

Similarly, there has been continuity in relations with China, with a solid framework for intensifying partnership (Current Affairs Correspondent East Asia, 2020). As noted earlier, Kazakhstan is a linchpin for trade and transport links on the Eurasian continent - for China's "Belt and Road Initiative" and beyond - due to its location, vast landmass, and energy reserves (Zogg, 2019). Not surprisingly, Kazakhstan has been consistently seeking further rapprochement with China especially in economic and security spheres (Rousseau, 2013). Thus, Tokayev is likely to take strides towards further strengthening the bilateral ties.

Notably, the new government has been working towards broadening ties with neighboring Central Asian countries. After Islam Karimov's death, there appears to be rapprochement with Uzbekistan. Namely, during his official visit to Tashkent, Tokayev signed several economic and military agreements with Uzbekistan's newly elected President Mirziyoyev. The counterparts agreed on several issues, including on the establishment of the International Centre for Trade and Economic Cooperation on their shared border (Altynbayev, 2019). Overall, despite the continuity in foreign policy, Tokayev appears to be pursuing ambitious and innovative foreign policy agenda, aimed making a longer list of regional and global allies.

\section{Conclusions}

This paper contributes to existing literature on the post-Nazarbayev state-building in Kazakhstan by examining domestic and foreign policy implications of the power transition. Based on the previous discussion, there are a few main concluding observations to make regarding Kazakhstan's post-Nazarbayev trajectory.

First and in terms of Nazarbayev's legacy, his successor Tokayev has inherited a country, characterizied by a prosperous economy, but an authoritarian political system. Kazakhstan keeps maintaining the core features of oil-rich countries, with hydrocarbon-based economy and regime stability stemming from an "authoritarian bargain" between state and society. This comes down to citizens relinquishing their political rights for economic security. Even though, it would be unrealistic to expect major economic and political breakthroughs under Tokayev's presidency, the he has emphasized the advancement of a young generation of policy makers. As a result, the elevation of the post-Soviet generation 
of professionals to the important positions of political leadership has gone underway, thus providing grounds for a cautious optimism about its positive implications for economic and political reforms.

Second and in terms of broader political implications of the power transition, the problems, related to human rights and political freedoms, including electoral irregularities, suppression of dissent, and even torture, as well as persecution have largely remained unaddressed. Meanwhile, the government does not appear to be taking considerable strides in eradicating such malpractices. Even though the freedom of assembly has slightly improved, there has not been much to reassure or reinforce the incumbents' promises and pledges of significant reforms.

Third and in terms of economic implications of the power transition, there has been little progress in terms of the structural transformation of the country's poorly diversified economy based on the accelerated development of the manufacturing industry, the increase in non-commodity exports and the attraction of foreign direct investment in non-commodity sectors. Overall, the success of Tokayev's economic agenda significantly depends on the broader anti-corruption efforts that have not yielded considerable results by far.

Last, and in terms of foreign policy implications of the power transition, despite the continuity in foreign policy, Tokayev appears to be pursuing ambitious and innovative foreign policy agenda. The latter includes further deepening and broadening partnership with all key partners, while seeking further rapprochement with Central Asian neighbors. Against this backdrop, intensifying partnership with post-Karimov Uzbekistan is remarkable.

\section{References}

Administration of Affairs of the President of the Republic of Kazakhstan. (2020). On the Foreign Policy Concept of the Republic of Kazakhstan for 2020-2030. Retrieved October 19, 2020, from https://ptrk.kz/en/on-the-foreign-policy-concept-of-the-republic-ofkazakhstan-for-2020-2030/.

Aitzhanova, A. (2014). Kazakhstan 2050: Toward a modern society for all. S. Katsu, J. F. Linn, \& V. Yezhov (Eds.). New Delhi: Oxford University Press.

Altynbayev, K. (2019). With Eye on Regional Security, Kazakhstan, Uzbekistan Ink New Military Cooperation Deals. Retrieved October 18, 2020, from https://central.asianews.com/en_GB/articles/cnmi_ca/features/2019/04/18/feature-01.

Altynsarina, E. (2019). New Kazakh President Makes First Foreign Visit to Moscow,

Reaffirms Priority of Relations. Retrieved October 18, 2020, from https://astanatimes.com/2019/04/new-kazakh-president-makes-first-foreign-visit-tomoscow-reaffirms-priority-of-relations/.

Amnesty International (2019). Everything You Need to Know about Human Rights in $\begin{array}{llll}\text { Kazakhstan. } & \text { Retrieved } & \text { October } & \text { 2020, from }\end{array}$ 
https://www.amnesty.org/en/countries/europe-and-central-asia/kazakhstan/reportkazakhstan/.

Aubakirova, G. M. (2020). Transformational Change in the Economy of Kazakhstan. Studies on Russian Economic Development, 31(1), pp. 113-119.

Bátor, P., Ondrejcsák R. (2016), Panorama of global security environment 2015-2016. Bratislava: Center for European and North Atlantic Affairs, 241-249.

BBC (2019). Kazakh Leader Nazarbayev Resigns after Three Decades. Retrieved October 14, 2020, from https://www.bbc.com/news/world-asia-47628854.

Blackburn, M. (2019). Discourses of Russian-speaking youth in Nazarbayev's Kazakhstan: Soviet legacies and responses to nation-building. Central Asian Survey, 38(2), pp. 217-236.

Boucher, D. and Kelly, P. (1994). The Social Contact and its Critics: An Overview. In D. Boucher \& P. Kelly (Eds.), The social contract from Hobbes to Rawls (pp. 1-34). London: Routledge.

Chebotaryov, A. (2020). Special Aspects of Kazakhstan's New Foreign Policy Concept. Retrieved October 18, 2020, from https://cabar.asia/en/special-aspects-of-kazakhstan-s-newforeign-policy-concept.

Collins, N. and Bekenova, K. (2017). Fueling the New Great Game: Kazakhstan, energy policy and the EU. Asia Europe Journal, 15(1), pp. 1-20.

Current Affairs Correspondent East Asia (2020). China-Kazakhstan Relations are Result of Endeavors \& Wisdom - Belt \& Road News. Retrieved October 19, 2020, from https://www.beltandroad.news/2020/09/14/china-kazakhstan-relations-are-a-result-ofendeavors-wisdom/.

Dave, B. (2008). The EU and Kazakhstan: Is the pursuit of energy and security cooperation compatible with promotion of human rights and democratic reforms? In Engaging Central Asia. The European Union's new strategy in the heart of Eurasia (pp. 43-67). CEPS Centre for European Policy Studies.

Del Sordi, A. (2016). Legitimation and the Party of Power in Kazakhstan. In Politics and legitimacy in post-soviet Eurasia (pp. 72-96). Palgrave Macmillan, London.

Desai, R. M., Olofsgård, A., \& Yousef, T. M. (2009). The logic of authoritarian bargains. Economics \& Politics, 21(1), pp. 93-125.

Elena, P., Anna, S., Zhanibek, Z. and Olefirenko, O. (2016). Towards Economic Security Through Diversification: Case of Kazakhstan. Journal of Security \& Sustainability Issues, 5(4).

Euronews (2010). Nazarbayev: "Economy First, then Politics". Retrieved October 17, 2020, from https://www.euronews.com/2010/01/15/nazarbayev-economy-first-then-politics

Fershtey, A. and Sharifzoda, K. (2019). Life in the Closet: The LGBT Community in Central Asia. Retrieved October 19, 2020, from https://thediplomat.com/2019/01/life-in-thecloset-the-lgbt-communityin-central-asia/.

Freedom House (2020). Kazakhstan. Retrieved October 19, 2020, from https://freedomhouse.org/country/kazakhstan/freedom-world/2019. 
Freedom House (2020). Kazakhstan. Retrieved October 19, 2020, from https://freedomhouse.org/country/kazakhstan/freedom-world/2020.

Gegelashvili, N. A. and Modnikova, I. (2019). Kazakhstan in the Light of the Trump Administrations Policy. USA \& Canada: ekonomika, politika, kultura, (9), pp. 92-107.

Gotev, G. (2020). Political Reform in Kazakhstan is also an Answer to a Global Problem. Retrieved October 20, 2020, from https://www.euractiv.com/section/centralasia/opinion/political-reform-in-kazakhstan-is-also-an-answer-to-a-global-problem/.

Grove, T. (2019). A Spy Case Exposes China's Power Play in Central Asia. Retrieved October 17, 2020, from https://www.wsj.com/articles/a-spy-case-exposes-chinas-powerplay-in-central-asia-11562756782.

Isaacs, R. (2010). 'Papa'-Nursultan Nazarbayev and the Discourse of Charismatic Leadership and Nation-Building in Post-Soviet Kazakhstan. Studies in Ethnicity and Nationalism, 10(3), pp. 435-452.

Janenova, S. and Knox, C. (2019). Combating corruption in Kazakhstan: A role for ethics commissioners? Public Administration and Development, 40(3), 186-195. doi:10.1002/pad.1873.

Janenova, S. and Knox, C. (2020). Combatting corruption in Kazakhstan: A role for ethics commissioners? Public Administration and Development, 40(3), pp. 186-195.

Kendall-Taylor, A. (2012). Purchasing power: Oil, elections and regime durability in Azerbaijan and Kazakhstan. Europe-Asia Studies, 64(4), pp. 737-760.

Knox, C., and Yessimova, S. (2015). State-society relations: NGOs in Kazakhstan. Journal of Civil Society, 11(3), pp. 300-316.

Konkakov, A. and Kubayeva, G. (2016). Progress in diversification of the economy in Kazakhstan. Discussion papers of DIW, Berlin, German Institute for Economic Research, (2016/8).

Kussainov, D. (2019). Kazakhstan's First Post-Nazarbayev Presidential Election Rosa-Luxemburg-Stiftung. $\quad$ Retrieved October 15, 2020, from https://www.rosalux.de/en/news/id/40570/kazakhstans-first-post-nazarbayev-presidentialelection?cHash=a14ccd53f6b8807a499cd9d7ce5fa3eb.

Lawrence, J. (2019). US-led Steppe Eagle Helps Build Kazakhstan into Stable Partner in Central Asia. Retrieved October 13, 2020, from https://www.stripes.com/news/us-ledsteppe-eagle-helps-build-kazakhstan-into-stable-partner-in-central-asia-1.587858.

Li, V. (2019). Kazakh Anti-Corruption Activist Gunned Down. Retrieved October 13, 2020, from https://www.occrp.org/en/daily/9844-kazakh-anti-corruption-activist-gunneddown.

Luhn, A. (2019). Kazakhstan's Capital Astana Renamed in Honour of Leader after He 'Steps down'. Retrieved October 20, 2020, from https://www.telegraph.co.uk/news/2019/03/20/kazakhstans-capital-astana-renamed-honourleader-steps/.

Marat, E. (2016). Post-violence regime survival and expansion in Kazakhstan and Tajikistan. Central Asian Survey, 35(4), pp. 531-548.

Mihr, A. (2020). Transformation and Development. Springer Nature Switzerland AG. Gewerbestrasse 11, 6330 Cham, Switzerland. 
NATO (2017). Relations with Kazakhstan. Retrieved October 18, 2020, from https://www.nato.int/cps/en/natohq/topics_49598.htm.

Nazarbayev, N. (2012). Address by the President of the Republic of Kazakhstan, Leader of The Nation. Strategy Kazakhstan 2050. Retrieved October 13, 2020, from https://strategy2050.kz/.

Nazarbayev, N. (2014). Послание Президента Республики Казахстан Н.Назарбаева народу Казахстана. 11 ноября 2014 г. - Официальный сайт Президента Республики Казахстан. Retrieved October 15, 2020, from https://www.akorda.kz/ru/addresses/poslanie-prezidenta-respubliki-kazahstan-nnazarbaevanarodu-kazahstana-11-noyabrya-2014-g.

Nezhina, T. G. and Ibrayeva, A. R. (2013). Explaining the role of culture and traditions in functioning of civil society organizations in Kazakhstan. Voluntas: International Journal of Voluntary and Nonprofit Organizations, 24(2), pp. 335-358.

OEC (2019). Kazakhstan. Retrieved October 19, 2020, from https://oec.world/en/profile/country/kaz .

OSCE (2016). Republic of Kazakhstan, Early Parliamentary Elections 20 March 2016 OSCE/ODIHR Election Observation Mission Final Report. Retrieved October 09, 2020, from https://www.osce.org/files/f/documents/d/e/226996.pdf.

OSCE. (2019). Republic of Kazakhstan Early Presidential Election 9 June 2019. ODIHR Election Observation Mission Final Report. Retrieved October 09, 2020, from https://www.osce.org/files/f/documents/2/7/434459_0.pdf.

Putz, C. (2019). Kazakhstan's Presidential Election: Protests, Arrests, and a Presidency for Tokayev. Retrieved October 15, 2020, from https://thediplomat.com/2019/06/kazakhstans-presidential-election-protests-arrests-and-apresidency-for-tokayev/.

Radio Liberty (2018). Nazarbaev Becomes Security Council's Chairman For Life. Retrieved October 19, 2020, from https://www.rferl.org/a/kazakhstan-nazarbaev-securitycouncil-chairman-for-life/29358887.html .

Rousseau, R. (2013). Kazakhstan: Continuous improvement or stalemate in its relations with China?. Strategic Analysis, 37(1), pp. 40-51.

Sanchez, W. (2020). The Future of US-Kazakhstan Relations. Retrieved October 18, 2020, from https://gjia.georgetown.edu/2020/05/28/the-future-of-us-kazakhstan-relations/

Security Council of the Republic of Kazakhstan (2020). Retrieved October 17, 2020, from https://elbasy.kz/en/security-council-republic-kazakhstan.

Seisembayeva, A. (2018). Kazakh President Given Right to Head National Security Council for Life. Retrieved October 17, 2020, from https://astanatimes.com/2018/07/kazakhpresident-given-right-to-head-national-security-council-for-life/.

Selmier II, W. T. (2020). Kazakhstan as logistics linchpin in the Belt and Road Initiative. In Kazakhstan's Diversification from the Natural Resources Sector (pp. 173-202). Palgrave Macmillan, Cham. 
Stronski, P. (2016). Kazakhstan at Twenty-five: Stable but Tense. Carnegie Endowment for International Peace. Retrieved October 13, 2020, from https://carnegieendowment.org/2016/02/04/kazakhstan-at-twenty-five-stable-but-tense-pub62642.

SWP (2019). An Era is Coming to an End in Kazakhstan. Retrieved October 14, 2020, from https://www.swp-berlin.org/en/point-of-view/2019/an-era-is-coming-to-an-end-inkazakhstan/.

Terzyan, A. (2020). Authoritarian Continuity: The State of Political Freedoms and Human Rights in Kazakhstan and Uzbekistan. Eurasia Research Digest, Number 4, pp. 113.

The Astana Times (2020). New Leaders but Same Course For Kazakhstan as Top Cabinets Filled With Fresh New Politicians. Retrieved October 20, 2020, from https://astanatimes.com/2020/05/new-leaders-but-same-course-for-kazakhstan-as-topcabinets-filled-with-fresh-new-politicians/.

Tileuberdi, M. (2020). Kazakhstan-EU Relations Entering a New Stage. Retrieved October 18, 2020, from https://www.euractiv.com/section/central-asia/opinion/kazakhstaneu-relations-entering-a-new-stage/.

Trading Economics (2020). Kazakhstan Corruption Rank. Retrieved October 19, 2020, from https://tradingeconomics.com/kazakhstan/corruption-rank .

US Department of State (2019). 2019 Country Reports on Human Rights Practices: Kazakhstan. Retrieved from https://www.state.gov/reports/2019-country-reports-on-humanrights-practices/kazakhstan/.

Vielmini, F. (2019). Foreign Policy Challenges for a Post-Nazarbayev Kazakhstan. Eurasiatica Monitoring Central Asia and the Caspian Area. doi:10.30687/978-88-6969-3762/011.

Zhelev, P. (2019, December). Enhancing Export Diversification in Resource-Rich Economies-Policies and Evidence from Kazakhstan. In SHS Web of Conferences (Vol. 71, p. 01002).

Zogg, B. (2019). Kazakhstan: A Centrepiece in China's Belt and Road. CSS Analyses in Security Policy, (249). Retrieved October 19, 2020, from https://www.researchcollection.ethz.ch/bitstream/handle/20.500.11850/362184/CSSAnalyse249-

EN.pdf?sequence $=2 \&$ isAllowed $=y$. 